\title{
Biosynthesis of Citric Acid using Distillery Spent Wash as a Novel Substrate
}

\section{Payal Aghera and Nikhil Bhatt*}

Post Graduate Department of Microbiology, Biogas Research and Extension Centre, Gujarat Vidyapith, Sadra - 382 320, India.

\begin{abstract}
The present work emphasizes on citric acid production from distillery spent wash containing carbohydrates that has been tested to be novel and potential substrate. Pre-treatment of distillery spent wash was studied in an anaerobic digestion by suspended growth system under shifting hydraulic retention time and organic loading rate as well as physicochemical parameters. Fungi strain PN12 was applied for citric acid production using raw post methanated waste (treated spent wash). A potent fungus was identified by molecular characterization ( $18 \mathrm{~S}$ rRNA). To find phylogenetic relatedness gene sequence of potent culture PN12 has been compared with other sp. gene sequences registered at database of NCBI and the phylogenetic tree was created by software. For enhancement of citric acid production was carried out in different nutritional and environmental parameters such as inoculum size ( 2 to $10 \%$ ), incubation period ( 24 to $144 \mathrm{~h}$ ), $\mathrm{pH}(2$ to 7$)$, temperature ( 25 to $37^{\circ} \mathrm{C}$ ), nitrogen source (organic and inorganic $0.1 \mathrm{~g} / \mathrm{L}$ ), phosphorus source $(0.1 \mathrm{~g} / \mathrm{L}$ ). The detection of enzymes activities specified that the pathway of pyruvate carboxylation enhanced, which proposed carbon flux to citric acid it was reorganized in strains. Analysis of biosynthesized products by UV/Vis spectrophotometer and HPLC. Initial sugar and consumed sugar determined by DNSA method and also estimated cell dry weight.
\end{abstract}

Keywords: Citric acid, Sequencing, Distillery spent wash, Anaerobic digestion, Enzymes.

*Correspondence: agherapayal07@gmail.com

(Received: 15 February 2019; accepted: 03 March 2019)

Citation: Payal Aghera and Nikhil Bhatt, Biosynthesis of Citric Acid using Distillery Spent Wash as a Novel Substrate, J Pure Appl Microbiol., 2019; 13(1):599-607 doi: 10.22207/JPAM.13.1.69

(c) The Author(s) 2019. Open Access. This article is distributed under the terms of the Creative Commons Attribution 4.0 International License which permits unrestricted use, sharing, distribution, and reproduction in any medium, provided you give appropriate credit to the original author(s) and the source, provide a link to the Creative Commons license, and indicate if changes were made. 


\section{INTRODUCTION}

Currently, trend increment of citric acid production due to many progressive uses upcoming to bright in various applied field. The probable application of citric acid in drug delivery, biopolymers, engineering of tissue and several additional promising biomedical uses Ashkan et al., (2010). Nowadays application of citric acid in various field such as pharmaceuticals, food processing industry, and other applied industry. Different type of raw substrates such as molasses and high rich carbohydrates compound have been applied as substrates for profitable citric acid production Soccol et al., (2006). Therefore, in this study we have selected inexpensive novel substrate distillery spent wash for production of citric acid by newly isolated Aspergillus fumigatus.

Various type of responsible citric acid producing microorganisms involving fungi such as Aspergillus niger, Aspergillus phoenicis, Aspergillus foetidus, Penicillium janthinellum, Aspergillus fonsecaeus, bacteria such as $B$. licheniformis, Corynebacterium spp., Arthrobacter paraffinens and yeasts, such as Yarrowia lipolytica, Hansenula anamola, Candida tropicalis, Candida citroformans, Candida oleophila, Candida guilliermondii, Vandenberghe et al., (2017). Characterization of various nutritional and environmental condition are involved for enhance production of citric acid and potential microbial growth. Bari et al., (2010)\& Lotfy et al.,(2007).

There are three steps for citric acid synthesis as per biochemical and metabolic point of view, the first step involving pyruvate pathway consider sugar degradation with the conversion of glucose into pyruvate; the second step indicate the carboxylation of pyruvate and oxidative decarboxylation of pyruvate; the third step stands for the tricarboxylic acid cycle and citric acid accumulation Papagianni et al., (2007).

\section{MATERIALS AND METHODS \\ Isolation, Screening Condition and Identification of Citric acid producing strain Isolation}

The novel citric acid producing potent culture PN12 was cultivated from compost pit, spoiled fruits, curd, dumping site, fertile soil etc. were collected from Sadra, Gandhinagar, Gujarat. 1 $\mathrm{g}$ of each samples were added into sterile distilled water e.g. $10 \mathrm{~mL}$ and then settle down for serial dilutions. From each dilution $0.1 \mathrm{~mL}$ spread on PDA plate and incubation condition at $30^{\circ} \mathrm{C}$ for 5 days.

\section{Screening Condition}

In order to study citric acid fermentation, for citric acid production there was 22 fungal cultures examined. In this study raw post methanated waste (treated spent wash) without any nutrient supplement was selected as fermentation medium in $250 \mathrm{~mL}$ Erlenmeyer flasks and inoculated fungal spore in a post methanated waste and then incubated at $30^{\circ} \mathrm{C}$ under shaking $120 \mathrm{rpm}$. After completion of $96 \mathrm{~h}$ incubation time the Whatman No. 41 was used for filter fermented broth and the supernatant was applied for analysis of citric acid production.

\section{Identification}

Based on screening condition for the selection of potent citric acid producing strain. The potent strain PN12 characterized by morphological and microscopic observation. Further validation was completed by 18s rRNA gene sequencing at GSBTM, Gandhinagar, India. (Genebank accession No. MH791044).

\section{Collection of spent wash for the citric acid} production and it's anaerobic digestion

In present study carbohydrate rich distillery spent wash collected from Madhi, Surat, Gujarat, India. The laboratory scale suspended growth reactor was constructed using glass anaerobic rector and active biogas slurry was inoculated into reactor. Suspended growth was develop for a period of 15 to 25 days till cell mass was enriched. Alternate feeding of spent wash with a HRT of 10 days initially operated for reactor. The HR Taltered from 10 to 5 days HRT with an increment of OLR. Constant COD and color reduction of the effluent judged at steady state condition.

\section{Inoculum preparation}

Spore inoculum of cultivated was made from 5 days active culture on potato dextrose agar slants at $30^{\circ} \mathrm{C}$. Spore suspension was developed from grown fungal mycelia with sterile distilled water to achieved a absolute amount of $\sim 1^{\prime} 10^{6}$ spores / mL.

Characterization of process parameter on citric acid production

A one at a time optimized various parameters conducted such as nutritional and 
environmental parameters. The experiments were conducted $250 \mathrm{~mL}$ flask containing $100 \mathrm{~mL}$ waste water (treated spent wash). After inoculation (fungi) maintain under following operational conditions.

Effect of inoculum size on production of citric acid Different inoculum size was taken and their effect noticed in terms of citric acid by selected fungal culture. The inoculum sizes from 2, 4, 6, 8 and $10 \% \mathrm{v} / \mathrm{v}$ to optimize and enhance production of citric acid.

Effect of incubation period on production of citric acid

Another important factor was incubation time optimization which can be evaluated by different incubation period at 24, 48, 72, 96 and $120 \mathrm{~h}$ to optimization and enhancement production of citric acid

Effect of $\mathrm{pH}$ on production of citric acid

Attempted for examine the optimum $\mathrm{pH}$ on production of citric acid with fungal culture, the $\mathrm{pH}$ of synthetic media was varied in range of 2,3 , $4,5,6$ and $7 \mathrm{pH}$ was adjusting using $1 \mathrm{~N} \mathrm{NaOH}$ and $1 \mathrm{~N} \mathrm{H}_{2} \mathrm{SO}_{4}$.

Effect of temperature for citric acid production

Temperatures optimize one of the most important parameters essential for the success of fermentation. Different temperature such as a 25 , $28,30,32,35,37$ and $40{ }^{\circ} \mathrm{C}$ studied to optimize and enhance production of citric acid.

Effect of nitrogen source on production of citric acid

Citric acid production was studied on different nitrogen source $(0.1 \mathrm{~g} / \mathrm{L})$ concentration of tryptone, malt extract, yeast extract, peptone, beef extract, urea, $\mathrm{NaNO}_{3}, \mathrm{NH}_{4} \mathrm{Cl}, \mathrm{NH}_{4} \mathrm{H}_{2} \mathrm{PO}_{4}, \mathrm{NH}_{4} \mathrm{NO}_{3}$ and $\left(\mathrm{NH}_{4}\right)_{2} \mathrm{SO}_{4}$.

Effect of percentage of $\mathrm{NH}_{4} \mathrm{NO}_{3}$ on production of citric acid

Different percentages of $\mathrm{NH}_{4} \mathrm{NO}_{3} 0.05,0.1$, $0.15,0.2,0.25$ and $0.3 \mathrm{~g} / \mathrm{L}$ were studied to optimize and enhance production of citric acid.

Effect of phosphorous source on production of citric acid

Various phosphorous source such as $\mathrm{K}_{2} \mathrm{HPO}_{4}, \mathrm{KH}_{2} \mathrm{PO}_{4}, \mathrm{Na}_{2} \mathrm{HPO}_{4}, \mathrm{NaH}_{2} \mathrm{PO}_{4}$ were performed for citric acid production.

Effect of percentage of $\mathrm{KH}_{2} \mathrm{PO}_{4}$ on production of citric acid

Various phosphorous source were investigated for enhance production of citric acid at concentration at ranged from 0.05 to $0.3 \mathrm{~g} / \mathrm{L}$.

\section{Enzymatic studies}

Preparation of cell free extract

Mycelium was harvested (regular time interval of $24 \mathrm{~h}$ ), washed with double distilled water until the $\mathrm{pH}$ was observed neutral, resuspended in $5 \mathrm{~mL}$ of phosphate buffer $(0.1$ $\mathrm{M}, \mathrm{pH}$ 7.4) comprising DTT (1 mM). Equal amount of glass beads was added in biomass to make a thin paste and homogenized by blender (maximum speed for $1 \mathrm{~min}$ ). Diluted homogenized suspension by an equalsize of phosphate buffer and filter by Whatman No. 41. Mixture was centrifuged at $15,000 \mu \mathrm{g}, 4^{\circ} \mathrm{C}$, for $25 \mathrm{~min}$ and crude enzyme collected as supernatant All experiments conducted at 0 to $4^{\circ} \mathrm{C}$.

Enzyme assay

Acotinase activity was detected at 240 $\mathrm{nm}$ and isocitrate dehydrogenase NAD and NADP

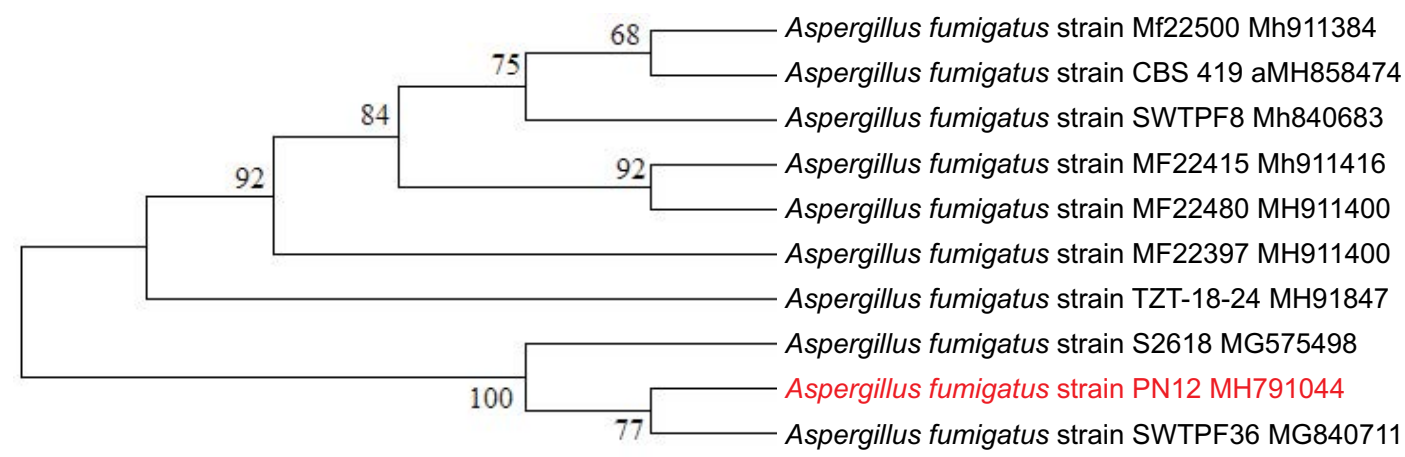

Fig. 1. Phylogenetic tree of strain PN12 
activity was measured Gupta et al., (2002). Enzyme activity defined as one unit of enzymatic activity change in absorbance $\mathrm{U} / \mathrm{mg}$ of protein of the enzyme. Total Proteins were quantified by Lowry et al., (1951) with standard as bovine serum albumin. All enzyme activities were done with triplicates.

\section{Analytical Method}

The fermented broth was filtered through

Whatman No. 41 to separate mycelia, and the filtrate was taken for analysis. Determination of citric acid done by pyridine-acetic anhydride method Ali et al., (2015). We also conformed HPLC analysis by an ultra violet and refraction index detector (UV/RID) and C18 $300 \mathrm{~mm}$ column. The functioned of column carried out at $65^{\circ} \mathrm{C}$ with $0.005 \mathrm{~mol} / \mathrm{L}$. The mobile phase used as a $\mathrm{H}_{2} \mathrm{SO}_{4}$ with $0.6 \mathrm{~mL} / \mathrm{min}$. Dry biomass estimated by gravimetric study. All investigation carried out with triplicates and samples collected from each was analyzed for production of citric acid. The results obtained in the present study was subjected to standard deviation (S.D).

\section{RESULTS AND DISCUSSION}

Isolation and phylogenetic analysis of culture PN12

In order to screen citric acid producing microbes were developed from compost pit, composting, spoiled fruits, curd, dumping site and farm soil of Sadra, Gandhinagar, Gujarat, India. 22 isolates were tested for production of citric acid in batch fermentation using post methanated waste without any nutrient supplement. The maximum citric acid production was obtained by culture PN12 which was promising for its ability to produce the maximum citric acid concentrations as indicated by HPLC and UV Visible analysis. Preliminary identification of fungal culture was done by morphological and microscopic examination. During morphological examination on PDA plate, the colony observed as velvet like whitish colony, which later turns to greenish. Microscopic examination resulted as conidial heads, shining, fragmented into stakes, green colored and calculated up to $260^{\prime} 260 \mu \mathrm{m}$ in size. The conidiophores found to be originated that appeared in greenish color lately. The fungal culture submitted as 18S rRNA gene sequence to NCBI (Accession No. MH791044). To find phylogenetic relatedness gene sequence of $A$. Fumigatus PN12 has been compared with other Aspergillus sp. gene sequences registered at NCBI database and the phylogenetic tree was generated using Mega 5.2 software.

Physicochemical characterization of distillery spent wash

Physico-chemical characterization of distillery spent was analyzed by individually parameters. The $\mathrm{pH}$, gravimetric analysis, chemical oxygen demanded, biological oxygen demanded, total Kjeldahl nitrogen, Reducing sugar, Total sugar, sodium and potassium detected using various methods as shown in Table 1.

Effect of inoculum size for citric acid production Inoculum volume is one of the important factor and the production activities

Table 1. Characteristic of Spent wash

\begin{tabular}{lllll}
\hline Factors & Units & Techniques & $\begin{array}{l}\text { Distillery } \\
\text { Spent Wash }\end{array}$ & $\begin{array}{l}\text { Methanated } \\
\text { Waste water }\end{array}$ \\
\hline $\mathrm{pH}$ & & & $3.5-4.5$ & $7.0-7.4$ \\
Reducing sugar & $\mathrm{mg} / \mathrm{L}$ & Dinitrosalicylic acid & $30,000-60,000$ & $40,000-50,000$ \\
Total sugar & $\mathrm{mg} / \mathrm{L}$ & Anthrone & $60,000-80,000$ & $55,000-70,000$ \\
COD & $\mathrm{mg} / \mathrm{L}$ & Close reflux method & $1,10,000-1,50,000$ & $50,000-80,000$ \\
BOD & $\mathrm{mg} / \mathrm{L}$ & Azide Modification & $30,000-40,000$ & $15,000-20,000$ \\
TS & $\mathrm{mg} / \mathrm{L}$ & Dried at $102 \pm 2^{\circ} \mathrm{C}$ & $1,10,000-1,50,000$ & $50,000-75,000$ \\
TDS & $\mathrm{mg} / \mathrm{L}$ & Dried at $102 \pm 2^{\circ} \mathrm{C}$ & $70,000-1,10,000$ & $45,000-65,000$ \\
TSS & $\mathrm{mg} / \mathrm{L}$ & Dried at $102 \pm 2^{\circ} \mathrm{C}$ & $10,000-12,000$ & $7,500-8,000$ \\
TVS & $\mathrm{mg} / \mathrm{L}$ & Dried at $550 \pm 2^{\circ} \mathrm{C}$ & $60,000-80,000$ & $18,000-24,0000$ \\
Sulphate & $\mathrm{mg} / \mathrm{L}$ & Turbidometric method & $5,000-6,500$ & $6,500-7,000$ \\
Phosphate & $\mathrm{mg} / \mathrm{L}$ & Colorimetric method & $1,500-1,650$ & $1,600-2,000$ \\
Total nitrogen & $\mathrm{mg} / \mathrm{L}$ & Total Kjeldahl method & $3,500-4,000$ & $2,000-2,500$
\end{tabular}


of microorganism are affected by change in inoculum size. Optimization study was carried out with the, PN12. Inoculum size plays an important role because of sufficient cell mass required to successfully convert substrates to product and also increase production of citric acid. Influence of inoculum size for citric acid production evaluated with addition of different inoculum ranged from 2.0 to $10 \%(\mathrm{~V} / \mathrm{V})$. The maximum production of citric acid $(3.05 \pm 0.25 \mathrm{~g} / \mathrm{L})$ attained with the inoculum size at $6 \% \mathrm{v} / \mathrm{v}$. A further increase or decrease than optimum inoculum concentration showed gradually decline in citric acid production (Fig. 2). The reason to this recognized to DO limitation and increase in competition towards nutrients for growth and metabolism affecting the product formation. Maharani et al., (2014) investigated higher citric acid production was achieved with inoculum size at $6 \%$ using $A$. niger. Adeoye et al., (2015) also tested the use of 2 to 10 $\%$ inoculum size for enhance citric acid $A$. niger.

Effect of incubation period for production of citric acid

Incubation time for fungi is several hours.

To performed influence of incubation period 24 to $144 \mathrm{~h}$ for citric acid production tested raw material showed in post methanated waste water. During fermentation, highest citric acid production ( $3.98 \pm$ $0.86 \mathrm{~g} / \mathrm{L}$ ) achieved with $96 \mathrm{~h}$ and there after failed progressively. Ali et al., (2015) suggested the best fungi growth and production time response to high yield of production depends on potent strain and growth maintained materials. Our data finding with Angumeenal et al., (2005) they observed highest production of citric acid noted after $96 \mathrm{~h}$. Barrington et al., (2008) investigated the highest achieved production of citric acid within $152 \mathrm{~h}$ and $120 \mathrm{~h}$ respectively from A.niger.

\section{Effect of $\mathrm{pH}$ for citric acid production}

Initial $\mathrm{pH}$ of culture medium is one of the key influences production of citric acid in fermentation. To investigate the consequence of $\mathrm{pH}$ on the fermentation media was varied ranged 2 to 7 using raw materials as post methanated waste water. In the present study highest citric acid production $(5.91 \pm 0.36 \mathrm{~g} / \mathrm{L})$ was noticed at $\mathrm{pH}$ 6.0. However, it was also monitored $A$. fumigatus exhibited good production in narrow $\mathrm{pH}$ range from 5.5 to 6.0 with marked less productivity at $\mathrm{pH}$ up to 6.5. Further decrease in $\mathrm{pH}$ production ability of $A$. fumigatus was subsequently reduced. For production of citric acid and culture growth was

Table. 2. The Effect on enzyme activities (U/mg protein) in A. fumigatus

\begin{tabular}{lcccccc}
\hline Enzymes & $12 \mathrm{~h}$ & $24 \mathrm{~h}$ & $48 \mathrm{~h}$ & $72 \mathrm{~h}$ & $96 \mathrm{~h}$ & $120 \mathrm{~h}$ \\
\hline $\begin{array}{l}\text { Acotinase } \\
\text { NAD + Isocitrate }\end{array}$ & $1.01 \pm 0.09$ & $1.64 \pm 0.12$ & $2.21 \pm 0.19$ & $2.80 \pm 0.08$ & $3.19 \pm 0.023$ & $2.54 \pm 0.01$ \\
$\begin{array}{l}\text { Dehydrogenase } \\
\text { NADP+ Isocitrate }\end{array}$ & $0.86 \pm 0.02$ & $1.56 \pm 0.06$ & $1.89 \pm 0.15$ & $2.50 \pm 0.23$ & $3.0 \pm 0.15$ & $2.34 \pm 0.10$ \\
Dehydrogenase & & & & & & \\
\hline
\end{tabular}

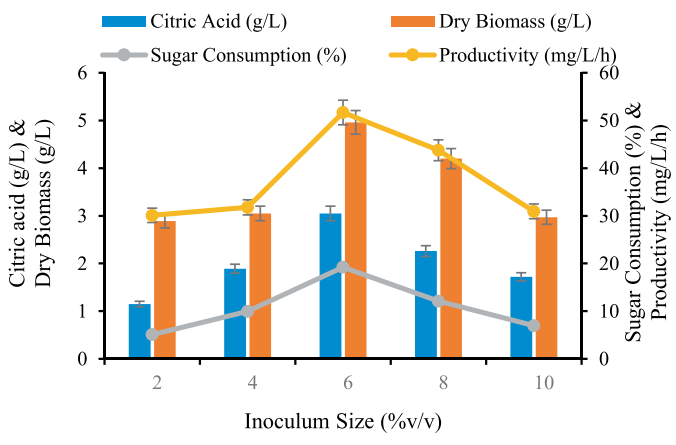

Fig. 2. Effect of inoculum size on production of citric acid

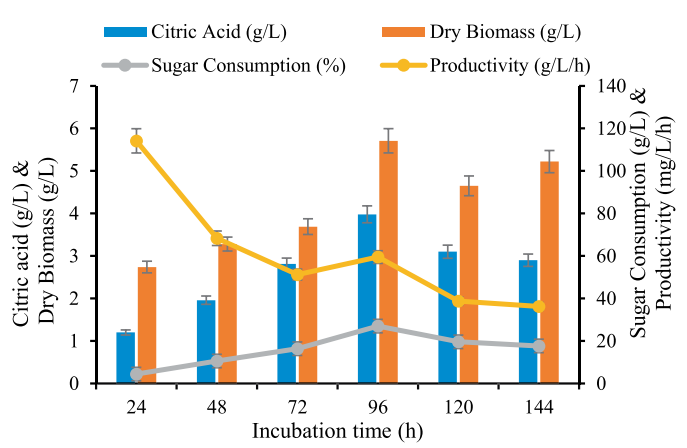

Fig. 3.Effect of incubationperiod for citric acid production 


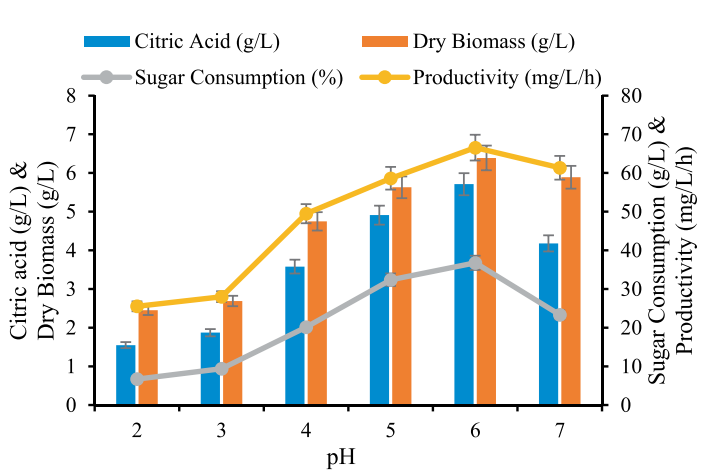

Fig. 4.Effect of $\mathrm{pH}$ for the citric acid production

observed in $\mathrm{pH}$ of approximately 3.0 to 6.0 Soccol et al., (2006). Emeka et al., (2012) have reported higher citric acid production by Aspergillus EGNOO3 at $\mathrm{pH}$ 5.5. However, substrate used as a banana peel by Aspergillus niger MTCC 282 has been investigated to increase drastically under 3 to 5 ranges Emeka et al., (2010).

Effect of temperature for citric acid production

The influence of temperature for production of citric acid is correlated to the organisms growth. Metabolic productivity is very sensitive to the incubation temperature. In present study, citric acid production conducted in a different ranged at 25 to $40^{\circ} \mathrm{C}$. The highest production of citric acid was achieved at $30^{\circ} \mathrm{C}$. It has been also tested at above $30^{\circ} \mathrm{C}$ temperature there was drastically affected on citric acid production. At temperature lower or higher than optimum, less citric acid production was observed. Ali et al., (2015) used arginine as a nutritional ingredient for citric acid production by $A$. ornatus at $30^{\circ} \mathrm{C}$. Walid et al., (2007) have been constituted the desired temperature at $31.5^{\circ} \mathrm{C}$ for maximum citric acid production. Xu et al., (2015) investigated best production of citric acid at $37.5{ }^{\circ} \mathrm{C}$ from

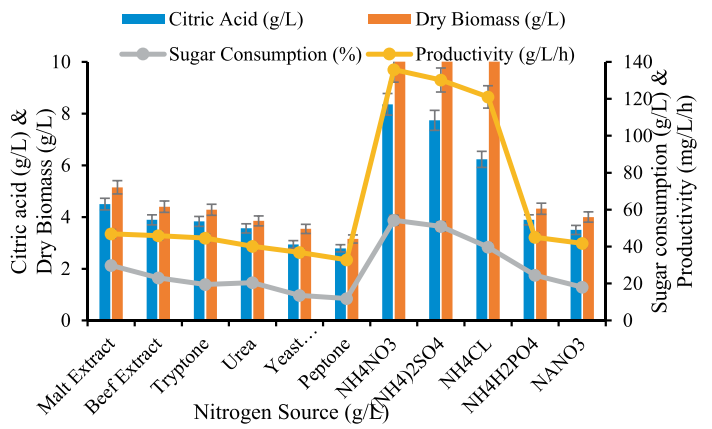

Fig. 6. Effect of nitrogen source on citric acid production.

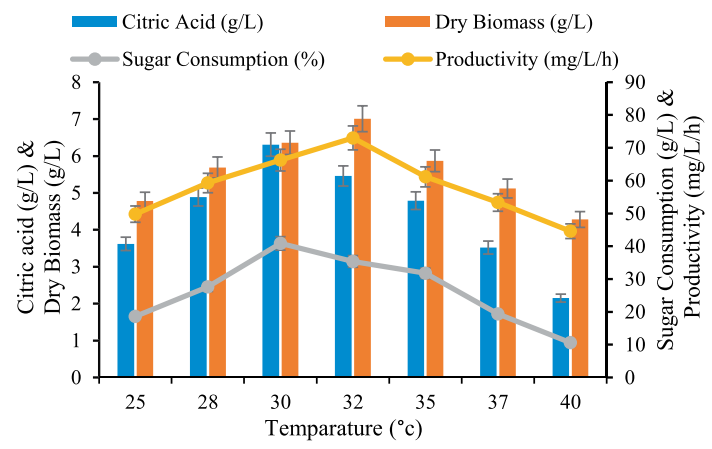

Fig. 5.Effect of temperature on citric acid production.

cassava and corn powder by A. niger.

Effect of Nitrogen Source for production of citric acid

Nitrogen sources have an important influence on the extent of citric acid production. To investigated influence of nutrient source for production of citric acid. various nitrogen source surplus separately to the treated spent wash. Amongst various type of nutrient source $\mathrm{NH}_{4} \mathrm{NO}_{3}$ was found to support maximum citric acid production $(8.36 \pm 0.56 \mathrm{~g} / \mathrm{L})$ which was enhanced nitrogen source than organic nitrogen sources. However, other inorganic nitrogen sources, $\left(\mathrm{NH}_{4}\right)_{2} \mathrm{SO}_{4}, \mathrm{NH}_{4} \mathrm{H}_{2} \mathrm{PO}_{4}$ and $\mathrm{NH}_{4} \mathrm{Cl}$ gave favorable response for citric acid production, and organic nitrogen sources reported less productivity of citric acid. Max et al., (2010) observed that in lab scale investigation are usually complemented with ammonia salt which responsible reduction in $\mathrm{pH}$ which gives favorable fermentation process.

Our results accordance with Yasser et al., (2012) who investigated $A$. niger produced maximum citric acid when $\mathrm{NH}_{4} \mathrm{NO}_{3}$ used as an inorganic nitrogen source from date syrup. However, Shankar et al., (2016) was also reported

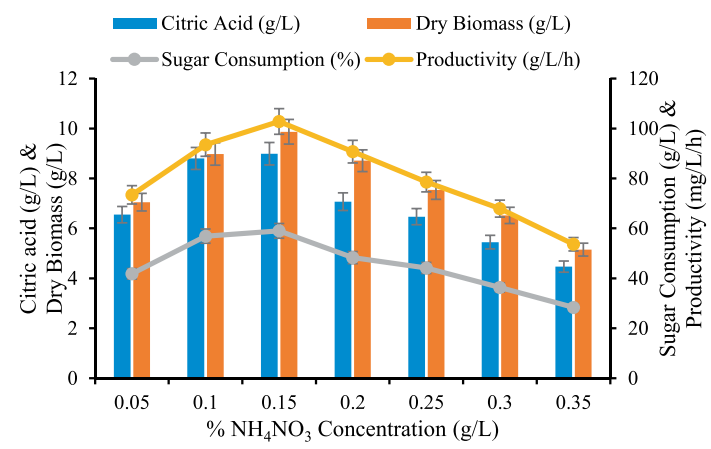

Fig. 7. Effect of $\% \mathrm{NH}_{4} \mathrm{NO}_{3}$ for production of citric acid 
$\mathrm{NH}_{4} \mathrm{Cl}$ as a best nitrogen source for enhance production of citric acid by $A$. niger. On the other hand the production of citric acid from Aspergillus niger ATCC 9142 with urea as a potent nitrogen source revealed by Darani et al., (2008).

\section{Effect of \% $\mathrm{NH}_{4} \mathrm{NO}_{3}$ for production of citric acid}

The result revealed that the $\mathrm{NH}_{4} \mathrm{NO}_{3}$ as a prominent source on synthesis of citric acid and its concentration ranged at 0.05 to $0.3 \%$. In present study concluded the $0.2 \%$ best range of production of citric acid. Ali et al., (2011) observed production of citric acid within $\mathrm{NH}_{4} \mathrm{NO}_{3}$ from paddy straw. We inspected that production of citric acid greatly effected by fungal culture correlated to the above or below at $0.2 \%$ of $\mathrm{NH}_{4} \mathrm{NO}_{3}$. It has been also inspected that increment of concentration of nitrogen source more than $0.2 \%$ resulted in a reduction in production of citric acid. Kareem et al. (2010) also observed the $\mathrm{NH}_{4} \mathrm{NO}_{3}$ as a good source for highest citric acid production.

Effect of Phosphorus source for production of citric acid

In direction to evaluated the influence of different phosphorus sources for the citric acid production. The citric acid production was higher while $\mathrm{KH}_{2} \mathrm{PO}_{4}$ used as a phosphrous source. Highest citric acid production was (8.01 $\pm 0.23 \mathrm{~g} / \mathrm{L}$ ) which was better than other sources of phosphrous. According to Papagianni et al., (2007) supplementary phosphate can enhanced stimulates biomass growth and secondary reactions. However, proved that CA gathered when phosphate restrictived, even absence of nitrogen. Effect of \% of $\mathrm{KH}_{2} \mathrm{PO}_{4}$ on citric acid production

$\mathrm{KH}_{2} \mathrm{PO}_{4}$ have an important influence on the extent of citric acid production. Fungal culture exhibited highest citric acid production when $\mathrm{KH}_{2} \mathrm{PO}_{4}$ added in the medium. In the present study, different ranged at 0.05 to $0.3 \%$ of $\mathrm{KH}_{2} \mathrm{PO}_{4}$ for enhance production of citric acid. To achieved results investigated high yield of citric acid $(10.2 \pm 0.14 \mathrm{~g} / \mathrm{L})$ with $0.1 \% \mathrm{KH}_{2} \mathrm{PO}_{4}$. It has been also noticed $\mathrm{KH}_{2} \mathrm{PO}_{4}$ concentration above 0.25 $\%$ reduced the citric acid production gradually. Qurban et al., (2017) has suggested comparable observation that the restriction of phosphorus source might be positively affect on citric acid production, while highly presented phosphate could reduction in fixation of $\mathrm{CO} 2$ and responsible for production of sugar acids.

\section{Enzymatic Study}

In order to conclude the biochemical rationale for regulation of CA production, Specific activities of acotinase, NAD+-isocitrate dehydrogenase and NADP+-isocitrate dehydrogenase were strain PN12 with respect to citric acid production. Induction of various enzymes during citric acid productive mechanism and also supports the active role of microorganisms in the synthesized process. As presented in Table. 2. Specific activity of acotinase in high CA yielding strains of $A$. fumigatus during the fermentation period of $96 \mathrm{~h}$. It was observed that the activity level of acotinase in PN12 was consistently higher throughout the entire period of fermentation. Gupta et al., (2002) was indicated that acotinase activity high during citric acid production using A.niger. But, NAD+ isocitrate dehydrogenase and NADP+ isocitrate dehydrogenase exhibited comparatively lower specific activities. That also noticed during fermentation production of citric acid high and lower as well as, the level of

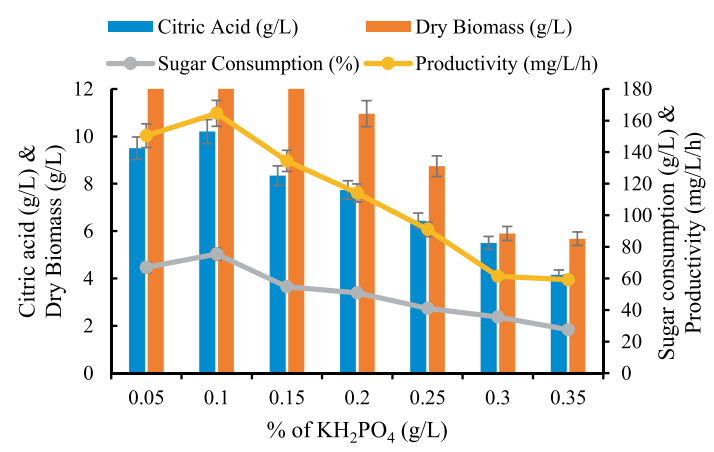

Fig. 9.Effect of $\%$ of $\mathrm{KH}_{2} \mathrm{PO}_{4}$ on citric acid production.

Fig. 8. Effect of phosphrous source on citric acid production 
acotinase, NAD+ isocitrate dehydrogenase and NADP+-isocitrate dehydrogenase was significantly increase and reduced.

\section{CONCLUSION}

Currently citric acid production trends widely due to economic importance so existing research work planned and attempted for optimize different processes. The optimization parameters carried out for enhancement of citric acid productivity and gained more productivity than initial condition. The production of citric acid by newly isolated Aspergillus fumigatus PN12 using economical post methanated waste under optimized condition. The potency of this fungi can be further improved by developing more precise and less costly methods for production of citric acid using priceless substrate. The citric acid production confirmed through HPLC analysis as well as biochemical rationale. In conclusion, distillery spent wash has prospective and novel to be a significant substrate used for synthesis of citric acid by Aspergillus fumigatus.

\section{ACKNOWLEDGEMENT}

None

\section{CONFLICT OF INTEREST}

The authors declare that there is no conflict of interest.

\section{REFERENCES}

1. Adeoye, A., Lateef, A. and Gueguimkana, E. Optimization of citric acid production using a mutant strain of Aspergillus niger on cassava peel Substrate. Biocatalysis and Agricultural Biotechnology, 2015; 15:1878-8181.

2. Ali, S., Anwar, Z., Irshad, M., Mukhtar, S. and Warraich, N. Bio-synthesis of citric acid from single and coculture-based fermentation technology using agrowastes. Journal of Radiation Research and Applied Sciences, 2015; $1-6$

3. Angumeenal, A. and Venkappayya, D. An overview of citric acid production. LWT - Food Science and Technology, 2013; 50:367-70.

4. Ashkan, T. N., Adeli, M. and Vossoughi, M. Poly (citric acid) block poly (ethylene glycol) copolymers new candidates for nanomedicine. Nanomedicine: Nanotechnology, Biology and Medicine. 2010;10: 1016.

5. Bari, N., Alam, Z., Muyibi, S. A., Jamal, P. and Al-Mamun, A. Statistical optimization of process parameters for the production of citric acid from oil palm empty fruit bunches. African Journal of Biotechnology. 2010; 9(4):
554-563.

6. Barrington, S. and Kim, J. Response surface optimization of medium components for citric acid production by Aspergillus niger NRRL 567 grown in peat moss. Bioresource Technology. 2008; 99: 368-377

7. Belen, M., Noelia, R., Sandra, C., Attilio, C. and Jose, M. biotechnological production of citric acid. Brazilian Journal of Microbiology, 2010; 41: 862-875.

8. Belge C. http://www.citriquebelge.com/our-company. aspx; 2015.

9. Darani, K. and Zoghi, A. Comparison of pretreatment strategies of sugarcane baggase: Experimental design for citric acid production. Bioresource Technology, 2008; 99; 6986-6993.

10. Ellaiah, P., Srinivasulu, B. andAdinarayana, K. Optimisation studies on neomycin production by a mutant strain of Streptomyces marinensis in solid state fermentation. Process Biochemistry, 2004; 39(5): 529-534.

11. Gupta, S. and Sharma, C. Biochemical studies of citric acid production and accumulation. World Journal of Microbiology andali Biotechnology, 2002; 18: 379-383.

12. Haq, I. U., Khurshid, S., Ali, S., Ashraf, H., Qadeer, M. A. and Rajoka, M. I. Mutation of Aspergillus of citric acid from black strap molasses. World Journal Microbiology. Biotechnology, 2001; 17: 35-37.

13. Kareem, S. O., Akpan, I. and Alebiowu, O. Production of citric acid by Aspergillus niger using pineapple waste. Malay Journal Microbiology, 2010; 16: 161-165.

14. Karthikeyan, A. and Sivakumar, N. Citric acid production by Koji fermentation using banana peel as a novel substrate. Bioresource Technology. 2010; 101: 55525556.

15. Kubicek, C. P. and Ryhr, M. Influence of manganese on enzyme synthesis and citric acid accumulation in Aspergillus niger. Applied Microbiology Biotechnology, 1977; 4:167-175.

16. Lotfy, W. A., Ghanem, K. M. and El-Helow, E. R. Citric acid production by a novel Aspergillus niger isolate: II. Optimization of process parameters through statistical experimental designs. Bioresource Technology, 2007; 98(18): 3470-3477.

17. Luciana, P., Vandenberghe., Soccol, C., Pandey, A., Lebeault, J. Solid-state fermentation for the synthesis of citric acid by Aspergillus niger. Bioresource Technology, 2000;74: 175- 178.

18. Maharani, V., Reeta, D., Sundaramanickam, A., Vijayalakshmi, S. and Balasubramanian, T. Isolation and characterization of citric acid producing Aspergillus niger from spoiled coconut. International Journal of Current Microbiology and Applied Sciences, 2014; 3(3): $\mathrm{x}-\mathrm{x} x$

19. Mourya, S. and Jauhri, K. S. Production of citric acid from starch-hydrolysate by Aspergillus niger. Microbiology. Resource, 2000;155: 37-44.

20. Nwoba Emeka, G., Ogbonna James, C., Ominyi Matthias, C., Nwagu Kingsley, E. and Gibson-Umeh, G. isolation of citric acid-producing fungi and optimization of citric acid production by selected isolates. Global Journal of Bio science and Biotechnology, 2012; 1 (2) : 261-270. 
21. Papagianni, M. Advances in citric acid fermentation by Aspergillus niger: biochemical aspects, membrane transport and modeling. Biotechnology Advances, 2007;25:244-63.

22. Qurban, H., Mohamed, M., Azzawi, Z. Economic benefit from the optimization of citric acid production from rice straw through Plackett-Burman design and central composite design. Turkish Journal of Engineering and Environmental Science, 2012; 36: 81 - 93.

23. Shankar, T. and Sivakumar, T. Optimization of Citric Acid Production Using Aspergillus niger Isolated from the Leaf Litter Soil of Sathuragiri Hills. Universal Journal of Microbiology Research, 2016; 4(4): 79-87

24. Shu, P. and Johnson, M. J. Citric acid production by submerged fermentation with Aspergillus niger. Industrial \& Engineering Chemistry Research, (1948); 40: 1202-1205.

25. Soccol, C., Luciana, P., Vandenberghe, Rodrigues, C. and Pandey, A. New Perspectives for Citric Acid Production and Application. Food Technology Biotechnoogyl, 2006; 44 (2): 141-149.

26. Vandenberghe, L., Rodrigues, C., Carvalho, D.,
Medeiros, A., Soccol, C. Production and Application of Citric Acid. Current Developments in Biotechnology and Bioengineering. 2017; 557-575.

27. Walid, A. L., Khaled, M.G. and Ehab, R.E., Citric acid production by a novel Aspergillus niger isolate: II optimization of process parameters through statistical experiments designs. Bioresource. Technology, 2007; 98: 3470-3477.

28. Xu, J., Chen, y., Zhang, H., Bao, J., Tang, L., Wang, K., Zhang, J., Chen, X. and Mao, Z. Establishment and assessment of an integrated citric acid-methane production process. Bioresource Technology, 2015; 176:121-128.

29. Yasser, S., Mostafa, A. and Alamri. Optimization of date syrup for enhancement of the production of citric acid using immobilized cells of Aspergillus niger. Saudi Journal of Biological Sciences, 2012; 19: 241-246

30. Zhang, A. and Roehr, M. Effect of varied phosphorus concentrations on citric acid fermentation by Aspergillus niger. Acta Biotechnology, 2002; 22: 383-390. 